\title{
KAJIAN KRITIS TERHADAP KETAHANAN PANGAN RUMAHTANGGA DAN FENOMENA STUNTING: KASUS PADA DUA DESA DI KECAMATAN GUNUNGSARI KABUPATEN LOMBOK BARAT
}

\section{CRITICAL ASSESSMENT OF HOUSEHOLD FOOD SECURITY AND STUNTING PHENOMENON: CASES IN TWO VILLAGES IN GUNUNGSARI DISTRICT, WEST LOMBOK REGENCY}

\author{
Siti Nurjannah $^{1 *}$, Syarifuddin ${ }^{2}$, Baiq Yulfia Elsadewi Yanuartati ${ }^{2}$ \\ ${ }_{1,2}$ Program Studi Sosiologi, Universitas Mataram, Kota Mataram \\ ${ }^{2}$ Program Studi Agribisnis Universitas Mataram, Kota Mataram \\ *Email Penulis Korespondensi : noekilyas@gmail.com
}

\begin{abstract}
ABSTRAK
Fenomena ketimpangan antara jumlah penduduk dan ketersediaan lahan makin tidak seimbang dewasa ini. Kondisi ini berdampak pada tidak terpenuhinya ketahanan pangan rumah tangga, gizi buruk, dan kejadian balita stunting. Tujuan penelitian adalah (1) Mengkaji ketahanan pangan rumahtangga yang mengalami kejadian stunting, (2) Menganalisis perilaku terhadap keragaman pangan, pola makan dalam hubungannya dengan kejadian stunting, (3) Mengetahui strategi dan upaya yang dilakukan dalam mengatasi masalah stunting. Penelitian ini menggunakan metode kuantitatif dan kualitatif dengan strategi penelitian studi kasus. Hasil penelitian menunjukkan bahwa ketahanan pangan rumah tangga masih dikategorikan agak rentan pangan karena keterbatasan dalam ketersediaan, stabilitas, aksebilitas dan keterjangkauan, kualitas dan keamanan pangan, sehingga melakukan strategi adaptasi untuk memenuhi pangan keluarga. Perilaku terhadap keberagaman pangan menunjukkan adanya keajegan antara sikap dan tingkah laku, ketidak ajegan dimana sikap tidak mempunyai hubungan dengan tingkah laku, dan adanya konsistensi kontingen dimana hubungan antara sikap dengan tingkah laku tergantung situasi tertentu. Penyebab stunting terdiri dari faktor ekonomi, sosial, lingkungan dan budaya. Beberapa strategi yang diupayakan untuk menurunkan stunting adalah meningkatkan kegiatan posyandu dan pemberian makanan sehat, penyuluhan tentang stunting dan memasyarakatkan tanaman kelor, membangun kampung KB.
\end{abstract}

Kata Kunci: Ketahanan Pangan Rumahtangga, Perilaku, Stunting

\begin{abstract}
The phenomenon of inequality between population numbers and land availability is increasingly unbalanced today. This condition has an impact on the unfulfillment of household food security, malnutrition, and the incidence of stunting toddlers. The purpose of the study is (1) Reviewing the food security of households experiencing stunting events, (2) Analyzing behaviors towards food diversity, diet in relation to stunting events, (3) Knowing the strategies and efforts made in overcoming the problem of stunting. This research uses quantitative and qualitative methods with case study research strategies. The results showed that household food security is still categorized as somewhat food vulnerable due to limitations in availability, stability, accessibility and affordability, food quality and safety, thus carrying out adaptation strategies to meet family food. Behavior towards food diversity indicates a disconnect between attitudes and behaviors, indecency where attitudes have no relation to behavior, and contingent consistency where the relationship between attitude and behavior depends on a particular situation. The causes of stunting consist of economic, social, environmental and cultural factors. Some of the strategies sought to reduce stunting are increasing posyandu activities and providing healthy food, counseling about stunting and practicing moringa plants, building KB villages.

Keywords: Household Food Security, Behavior, Stunting
\end{abstract}

\section{PENDAHULUAN}

Persoalan pangan sangat kompleks, mulai dari ketidakcukupan produksi bahan pangan, kesulitatan distribusi, fluktuasi harga yang tajam, alih fungsi lahan, aturan dan kelembagaan yang tumpang tindih. Hal ini mengancam ketahan pangan nasional dan menimbulkan keresahan pada masyarakat (Zid \& Alkhudri, 2016). Hasil penelitian Organisasi Pangan 
Dunia (FAO, 2016), terdapat 19,4 juta penduduk Indonesia diperkirakan masih mengalami kelaparan. Penyebab utamanya ialah kemiskinan dan kelangkaan bahan makanan pokok. Jumlah anak balita dengan status gizi buruk dan gizi kurang di daerah rawan pangan biasanya juga cukup banyak. Kondisi ini menunjukkan bahwa ketahanan pangan di tingkat nasional atau wilayah tidak selalu berarti bahwa tingkat ketahanan pangan di rumahtangga dan individu juga terpenuhi.

Menurut data World Health Organization (WHO), Indonesia termasuk ke dalam negara ketiga di Asia Tenggara dengan prevalensi balita stunting sebanyak 36.4\% pada tahun 20052017. Kejadian balita stunting merupakan masalah gizi utama yang dihadapi Indonesia. Pemenuhan gizi yang belum tercukupi dengan baik pada ibu hamil dapat menyebabkan terjadinya masalah kesehatan pada ibu maupun bayi yang ada di kandungannya.

Provinsi Nusa Tenggara Barat mengalami kasus stunting cukup tinggi hingga masuk ke dalam zona merah kasus stunting di Indonesia, dan peningkatan dari tahun 2016 yaitu sebanyak 29.9\% menjadi 37.20\% pada tahun 2017 (Dinas Kesehatan NTB, 2017). Jumlah kasus stunting di Kabupaten Lombok Barat sudah dapat diturunkan, namun kasus stunting masih cukup banyak. Berdasarkan hasil pemeriksaan Puskesmas Gunungsari tahun 2019 tercacat sebanyak 58 anak balita terkena stunting.

Pertanyaan mendasar yang perlu dikaji dalam penelitian ini adalah bagaimana hubungan ketahanan pangan rumahntangga, pemahaman tentang keragaman pangan, pola makan dengan kasus stunting, dan bagaimana upaya yang dilakukan untuk mengurangi stunting. Oleh karena itu perlu dilakukan penelitian tentang Kajian terhadap ketahanan pangan rumahtangga dan Fenenomena Stunting: Kasus dua desa di Kecamatan Gunungsari Kabupaten Lombok Barat. Tujuan yang hendak dicapai melalui penelitian ini adalah untuk (1) Mengkaji ketahanan pangan rumahtangga yang mengalami kejadian stunting, (2) Menganalisi perilaku terhadap keragaman pangan, pola makan dalam hubungannya dengan kejadian stunting, (3) Mengetahui strategi dan upaya yang dilakukan dalam mengatasi masalah stunting

\section{METODE PENELITIAN}

Penelitian ini menggunakan pendekatan kuantitatif dan kualitatif. Pendekatan kuantitatif dipergunakan untuk menganalisis perilaku rumah tangga responden terhadap ketahanan pangan dan stunting. Pendekatan kualitatif digunakan untuk memahami perilaku responden yang bersifat subyektif, dengan melihat pemahaman, sikap, dan pandangan yang bersifat emik terhadap ketahanan pangan dan stunting. Penelitian ini dilaksanakan di dua desa di Kecamatan Gunungsari Kabupaten Lombok Barat, yaitu Desa Penimbung dan Desa Mambalan. Pemilihan kedua Desa ini dilakukan secara sengaja atau "purposive sampling" atas dasar pertimbangan bahwa kedua desa ini terdapat banyak kasus stunting.

Responden dalam penelitian ditetapkan secara purposive sampling sesuai dengan tipikal kasus yang dikaji dan ditentukan sebanyak 40 rumah tangga dengan kasus stunting. Pendekatan studi kasus meupakan suatu proses pengkajian dan pengumpulan data secara mendalam dan detail seputar kejadian khusus, dengan menggunankan triangulasi teknik pengumpulan data yaitu wawancara mendalam, pengamatan, dan penelusuran dokumen. Kasus yang dianalisis dalam kajian adalah ketahanan pangan rumahtangga, perilaku keragaman pangan dan strategi mengatasi stunting (Neuman, 1994; Creswell, 1994, Nisbet \& Watt , 1994)

Variabel dalam penelitian ini (1) ketahanan pangan rumahtangga terdiri dari beberapa faktor yang meliputi: ketercukupan ketersediaan pangan, Stabilitas pangan, Aksebilitas dan keterjangkauan terhadap pangan, Kualitas dan keamanan pangan, Strategi adaptasi, (2) Pengetahuan, sikap, keterampilan dan tindakan yang ada responden dalam kaitannya dengan 
keragaman pangan dalam pola makan dan hubungannya dengan kejadian stunting, (3) Starategi mengatasi Stunting upaya yang dilakukan dalam rangka menurunkan angka kasus stunting.

Analisis data dilakukan dengan menggunakan metode analisa data kuantitatif dan kualitatif. Data kuantitatif akan diolah dan dianalisis dengan menggunakan metode atau teknik analisis data kuntitatif seperti rata-rata, persentase. Sementara itu, data kualitatif yang diperoleh akan diolah dengan menggunakan teknik siklikal dan dengan langkah-langkah sebagai berikut: pengumpulan data Reduksi data, Penyajian data dan Penarikan kesimpulan (Miles \& Huberman, 1992)

\section{HASIL DAN PEMBAHASAN}

\section{Gambaran Umum Stunting di Desa Mambalan dan Desa Penimbung}

Fenomena dapat dilihat dari status gizi atautinggi badan, gambaran kasus stunting di dua desa penelitian dapat dilihat dalam Tabel 1 berikut ini:

Tabel 1. Gambaran Umum Stunting di Desa Mambalan dan Desa Penimbung Tahun 2020

\begin{tabular}{llrrrr}
\hline No & Ukuran stunting & \multicolumn{2}{c}{ Desa Mambalan } & \multicolumn{2}{c}{ Desa Penimbung } \\
& Jumlah & $\begin{array}{c}\text { Persentase } \\
(\%)\end{array}$ & Jumlah & Persentase (\%) \\
\hline 1 & Pendek & 36 & 83,72 & 49 & 83,05 \\
2 & Sangat Pendek & 7 & 16,28 & 10 & 16,95 \\
\hline \multicolumn{2}{r}{ Jumlah } & 43 & 100 & 59 & 100 \\
\hline
\end{tabular}

Sumber : Monografi Desa 2020

Data di atas menunjukkan bahwa masih terdapat kasus stunting dengan kondisi sangat pendek sebanyak 7 orang $(16,7 \%)$ di Desa Mambalan 10 orang (16,95\%) di Desa Penimbung. Keadaan ini tentunya perlu mendapat perhatian yang lebih serius dan mencari upaya dalam mengatasi stunting. Selain itu kasus pendek pada dua desa tersebut menunjukkan angka yang cukup besar dimana terdapat 36 orang $(83,72 \%)$ di Desa Mambalan dan 49 orang $(83,05 \%)$ di Desa Penimbung. Berbagai strategi sdh dilakukan untuk mengatasi stunting di kedua desa penelitian dan upaya tersebut akan berhasil dengan baik jika terjadi kerjasama anatara orang tua yang mempunyai kasus stunting dengan pihak pemerintah desa, puskesmas dan kader desa yang mendampingi penyembuhan stuntaing.

\section{Karakteristik Responden}

Karakteristik responden yang terdiri dari umur, pendidikan, jumlah tanggungan, pekerjaan pokok dan pekerjaan sampingan disajikan sebagai berikut

a. Umur Responden

Hasil penelitian menunjukkan bahwa rata-rata umur responden dalam penelitian ini adalah 31 tahun dengan kisaran antara 19 tahun sampai dengan 50 tahun. Sebagian besar responden berada pada kelompok umur antara 30 hingga 50 tahun atau sebagian besar responden masih berada pada usia produktif - Tabel 2

Tabel 2. Sebaran Responden Berdasarkan Kisaran Umur di Kecamatan Gunungsari Tahun 2020

\begin{tabular}{cccc}
\hline No & Kisaran Umur Responden & Jumlah (Orang) & Persentase (\%) \\
\hline 1 & $19-30$ & 18 & 7,2 \\
\hline 2 & $31-40$ & 20 & 8,0 \\
\hline 3 & $41-50$ & 2 & 0,8 \\
\hline & Jumlah & 40 & 100
\end{tabular}

Sumber: Data primer diolah

Nurjannah, S., Syarifuddin., dan Yanuartati, B.Y.E 


\section{b. Tingkat pendidikan}

Data hasil penelitian menunjukkan bahwa sebagian besar petani responden (55\%) tamat Sekolah Dasar, dan responden yang memiliki pendidikan SMP ke bawah mencapai $80 \%$. Data juga menunjukkan hanya ada $20 \%$ responden yang tamat SMA dan tamat Perguruan Tinggi - Tabel 3

Tabel 3. Sebaran Responden berdasarkan Tingkat Pendidikannya Tahun 2020

\begin{tabular}{clcc}
\hline \multirow{2}{*}{ No } & Tingkat Pendidikan & Jumlah (Orang) & Persentase (\%) \\
\hline 1 & Tidak Tamat SD & 2 & 5 \\
\hline 2 & Tamat SD & 22 & 55 \\
\hline 3 & Tamat SMP & 8 & 20 \\
\hline 4 & Tamat SMA & 5 & 12,5 \\
\hline 5 & Perguruan Tinggi & 3 & 7,5 \\
\hline & Jumlah & 40 & 100 \\
\hline
\end{tabular}

Sumber: Data primer diolah

Berbagai kajian menunjukkan bahwa tingkat pendidikan akan mempengaruhi kemampuan seseorang dalam menerima informasi dan menerapkan yang dapat membantu dalam mengatasi stunting. Data di atas menggambarkan bahwa Pendidikan ibu yamg rendah berkontribusi pada pemahaman tentang kejadian stunting pada anaknya, sehingga intensitas penyuluhan perlu ditingkatkan dalam mengeliminir kasus stunting.

c. Jumlah Tanggungan Keluarga

Berdasarkan hasil penelitian menunjukkan bahwa rata-rata tanggungan keluarga di dua lokasi penelitian adalah 2 orang dengan kisaran 1-5 orang. Jumlah tanggungan berpengaruh pada ketersedian pangan rumahtangga, semakin besar jumlah tanggungan maka kebutuhan akan pangan semakin meningkat. Sebaran responden berdasarkan jumlah tanggungan keluarga disajikan dalam tabel berikut.

Tabel 4. Sebaran Responden menurut Jumlah Tanggungan Keluarganya Tahun 2020

\begin{tabular}{cccc}
\hline No & Jumlah Tanggungan & Jumlah (Orang) & Persentase (\%) \\
\hline 1 & $1-2$ & 23 & 57,5 \\
\hline 2 & $3-4$ & 16 & 40,0 \\
\hline 3 & $>5$ & 1 & 2,5 \\
\hline & Jumlah & 40 & 100 \\
\hline
\end{tabular}

Sumber: Data primer diolah

Berdasarkan tabel di atas, dapat diketahui bahwa sebagian besar responden memiliki tanggungan keluarga antara 1-2 orang sebanyak $57,5 \%$ atau 23 orang petani responden, 3-4 orang sebanyak $40 \%$ atau 16 orang petani responden, dan yang mempunyai tanggungan keluarga sama atau lebih dari 5 orang sebanyak $2,5 \%$ atau sebanyak 1 orang responden.

d. Pekerjaan Responden

Analisis terhadap pekerjaan responden mangacu pada pekerjaan suami dan istri. Pekerjaan pokok suami sebagian besar adalah buruh sebanyak 28 orang (70\%) dan 12 orang $(30 \%)$ bekerja serabutan, dan hanya 1 orang $(2,5 \%)$ yang mempunyai pekerjaan sampingan, sedangkan 39 orang $(97,5 \%)$ tidak mempunayi pekerjaan sampingan.

Selain suami ada beberapa istri yang ikut mengambil peran dalam mendukung keberlangsungan pangan rumah tangg dengan bekerja. Pekerjaan pokok istri membuka warung sebanyak 6 orang $(15 \%), 4$ orang $(10 \%)$ sebagai buruh dan 30 orang $(75 \%)$ tidak mempunyai pekerjaan pokok. Untuk pekerjaan sampingan 40 orang $(100 \%)$ istri tidak

Nurjannah, S., Syarifuddin., dan Yanuartati, B.Y.E 
mempunyai pekerjaan sampinga Pekerjaan pokok dan sampingan istri responden disajikan pada Tabel 5 berikut ini.

Tabel 5. Sebaran Responden Menurut Jenis Pekerjaan Istri Tahun 2020

\begin{tabular}{llcccc}
\hline \multirow{2}{*}{ No } & \multirow{2}{*}{ Jenis Pekerjaan } & \multicolumn{2}{c}{ Jenis Pokok } & \multicolumn{2}{c}{ Pekerjaan sampingan } \\
& & Orang & Persentase & Orang & Persentase \\
\hline 1 & Petani & 0 & 0 & 0 & 0 \\
2 & Pedagang & 6 & 15 & 0 & 0 \\
3 & Pegawai & 0 & 0 & 0 & 0 \\
4 & Buruh & 4 & 10 & 0 & 0 \\
5 & Lainnya & 0 & 0 & 0 & 0 \\
6 & Tidak bekerja & 30 & 75 & 40 & 100 \\
\hline & Jumlah & 40 & 100 & 40 & 100 \\
\hline
\end{tabular}

Sumber: Data primer diolah

\section{Ketahanan Pangan Rumah Tangga}

Ketahanan pangan rumah tangga yang dianalisis adalah Ketercukupan ketersediaan pangan, stabilitas pangan, aksebilitas dan keterjangkauan terhadap pangan, kualitas dan keamanan pangan, dan strategi adaptasi. Hasil penelitian menunjukkan bahwa ketahanan pangan rumah tangga masih dikategorikan agak rentan pangan. Sejalan dengan hasil penelitian terdahulu banwa Rumahtangga petani menurut distribusi Angka Kecukupan Energi (AKE) masih banyak yang belum cukup asupan energinya atau tidak tahan pangan, meskipun menurut rata-rata asupan energi rumahtangga petani termasuk tahan pangan. Sebagian besar Rumahtangga petani menurut PPP tergolong dalam kategori tidak tahan pangan. Keragaman ketahanan pangan rumahtangga petani terdistribusi sebagian besar masuk ke dalam kategori tidak tahan pangan (34,29 persen rawan pangan, 17,14 persen kurang pangan dan rentan pangan 11,43 persen), dan tahan pangan (37,14 persen) (Sauqi, et al., 2019)

\section{a. Ketercukupan Ketersediaan Pangan}

Ketercukupan ketersediaan pangan menggambarkan tentang sumber pangan bagi responden. Hasil penelitian menunjukkan bahwa responden tidak memproduksi sendiri untuk konsumsi pangan, karena mereka tidak mempunyai lahan pertanian, hal ini terkait dengan pekerjaan responden yang sebagian besar bekerja sebagai buruh dengan upah harian. Suhardjo (1989) mengatakan jika kebutuhan pangan banyak tergantung pada apa yang dibelinya, maka penghasilan (daya beli) harus sanggup membeli bahan makanan yang mencukupi baik kuantitas maupun kualitasnya. Sumber pangan bagi responden dapat dilihat dari tabel berikut.

Tabel 6. Sebaran Responden menurut Sumber Pangan Tahun 2020

\begin{tabular}{cccc}
\hline No & Sumber Pangan & Jumlah (Orang) & Persentase (\%) \\
\hline 1 & Beli & 31 & 77,5 \\
2 & Bantuan & 9 & 22,5 \\
\hline & Jumlah & 40 & 100 \\
\hline
\end{tabular}

Sumber: Data primer diolah

Tabel di atas menunjukkan bahwa sumber pangan responden dengan melakukan transaksi pembelian sebanyak 31 orang $(77,5 \%)$, sedangkan 9 orang $(22,5 \%)$ memperoleh bantuan dari pemerintah untuk keluarga pra sejahtera.

b. Stabilitas Pangan

Stabilitas pangan merujuk pada ketersediaan pangan yang dikonsumsi rumahtangga. Hasil penelitian menunjukkan bahwa setiap rumah tangga responden selalu berusaha untuk 
menyediakan bahan makanan pokok dengan tujuan stabilitas pangan dapat terpenuhi. Sebagian besar responden menyatakan bahwa beras merupakan bahan pangan yang paling utama dan tidak menggantikan dengan bahan makanan pokok lainnya seperti yang dijelaskan dalam tabel berikut

Tabel 7. Sebaran Responden menurut Jenis Makanan Pengganti Tahun 2020

\begin{tabular}{cccc}
\hline No & Jenis Pangan Pengganti & Jumlah (Orang) & Persentase (\%) \\
\hline 1 & Jagung & 0 & 0 \\
2 & Ubi kayu & 4 & 10 \\
3 & Ubi jalar & 0 & 0 \\
4 & Lainnya & 2 & 5 \\
5 & Tidak mengganti & 34 & 85 \\
\hline & Jumlah & 40 & 100
\end{tabular}

Sumber: Data primer diolah

Data pada tabel di atas menunjukkan bahwa terdapat 6 orang yang menggantikan bahan makanan pokok dengan jenis lainnya, dimana terdapat 4 orang $(10 \%)$ menggantikan dengan ubi kayu, dan 2 orang (5\%) menggantikan dengan pangan lainnya seperti talas dan lain lain, dan 34 orang $(85 \%)$ tidak menggantikan bahan makanan pokok. Responden yang menggantikan bahan makanan pokok diperoleh dengan cara membeli. Tindakan ini dilakukan responden karena harga relatif murah dibandingkan dengan harga beras, dan disesuaikan dengan pendapatan yang diperoleh.

c. Aksebilitas dan Keterjangkauan Terhadap Pangan

Aksebilitas dan keterjangkauan terhadap pangan menyangkut daya beli yang tergantung pada pendapatan rumahtangga, pengeluaran pangan, ukuran dan komposisi rumahtangga, harga pangan. Rata rata pendapatan responden Rp. 1.657 .500 per bulan dengan kisaran Rp. 500.000 - Rp. 3.000.000. per bulan. Pendapatan responden dijelaskan dalam tabel berikut

Tabel 8. Sebaran Responden Menurut Pendapatan, 2020

\begin{tabular}{cccc}
\hline No & Jumlah Pendapatan & Jumlah (Org) & Persentase (\%) \\
\hline 1 & $<1000.000$ & 5 & 12,5 \\
2 & $1000.000-1.500 .000$ & 21 & 52,5 \\
3 & $>1.500 .000$ & 14 & 35 \\
\hline & Jumlah & 40 & 100
\end{tabular}

Sumber: Data primer diolah

Tabel di atas menunjukkan bahwa Sebagian besar responden mempunyai pendapatan dengan kisaran Rp. 1.000 .000 - Rp. 1.500 .000 sebanyak 21 orang $(52,5 \%)$, pendapatan di atas Rp. 1.500 .000 sebanyak 14 orang (35\%), dan hanya 5 orang $(12,5 \%)$ yang mempunyai penghasilan di bawah Rp. 1.000.000.

Pendapatan tersebut dimanfaatkan responden untuk memenuhi kebutuhan hidup sehari hari. Rata rata pengeluaran responden untuk pangan sebesar Rp. 1.215.000 per bulan, dan rata rata pengeluaran non pangan sebesar Rp. 106.975 per bulan. Pengeluaran responden dapat dilihat dalam tabel berikut ini.

Tabel 9. Sebaran Responden Menurut Jenis Pengeluarannya Tahun 2020

\begin{tabular}{clcccc}
\hline \multirow{2}{*}{ No } & \multirow{2}{*}{ Jenis Pengeluaran } & \multicolumn{2}{c}{ Pengeluaran Pangan } & \multicolumn{2}{c}{ Pengeluaran Non Pangan } \\
\cline { 3 - 6 } & & Orang & Persentase & Orang & Persentase \\
\hline 1 & $<500.000$ & 1 & 2,5 & 40 & 100 \\
2 & $500.000-1.000 .000$ & 16 & 40 & 0 & 0 \\
3 & $>1.000 .000$ & 23 & 57,5 & 0 & 0 \\
\hline \multicolumn{2}{l}{ Jumlah } & 40 & 100 & 40 & 100 \\
\hline
\end{tabular}

Sumber: Data primer diolah

Nurjannah, S., Syarifuddin., dan Yanuartati, B.Y.E 
Tabel di atas menunjukkan bahwa 23 orang (57,5\%) mempunyai pengeluaran untuk pangan di atas Rp. 1.000.000, 16 orang (40\%) Rp. 500.000 - Rp. 1.000 .000 dan 1 orang $(2,5 \%)$ di bawah Rp. 500.000. untuk pengeluaran non pangan semua responden yaitu sebanyak 40 orang (100\%) mempunyai pengeluaran non pangan di bawah Rp. 500.000.

Untuk mendapatkan kebutuhan pangan, responden mengakses dengan membeli di warung dan di pasar. 35 orang $(87,5 \%)$ membeli kebutuhan di warung, dan 5 orang $(12,5 \%)$ membeli di pasar. Jarak antara kediaman responden dengan warung dan pasar kurang lebih 800 meter, sehingga tidak ada kendala dalam akses. Rutinitas belanja dilakukan setiap hari, hal ini berkaitan dengan pekerjaan responden sebagai buruh. Hardjana (1993) dan Adi (1997) mengatakan semakin tinggi tingkat daya beli semakin besar proporsi rumahtangga tahan pangan. Uji statistik menunjukkan adanya pengaruh yang bermakna antara daya beli dengan kejadian rumahtangga tahan pangan. Faktor daya beli jelas dipengaruhi oleh pendapatan rumahtangga, semakin tinggi tingkat pendapatan maka kemampuan daya beli pangan meningkat.

\section{d. Kualitas dan Keamanan Pangan}

Kualitas dan keamanan pangan menyangkut jenis pangan yang dikonsumsi baik pangan yang bersumber dari karbohidrat, lemak dan protein. Intensitas makan dalam sehari tiga kali dengan variasi makanan cukup beragam. Sebagian besar responden 33 orang (82,5\%) sudah mengkonsumsi sayur dan 7 orang (17,5\%) tidak mengkonsumsi sayur mayur. Untuk varian lauk yang dikonsumsi didominasi dengan tempe, tahu, ikan tongkol. Untuk varian makanan balita dapat dikatakan belum terlalu beragam, umumnya konsumsi makanan bayi tempe, tahu dan sayur, hanya 7 orang $(17,5 \%)$ yang menambahkan telur makanan balita, 1 orang $(2,5 \%)$ menambah ayam, dan 1 orang $(2,5 \%)$ menambah ikan nila. Untuk makanan tambahan 2 orang $(5 \%)$ yang memberikan susu pada balita.

\section{e. Strategi adaptasi}

Strategi adaptasi merupakan upaya yang dilakukan oleh rumahtangga untuk memenuhi kebutuhan pangan keluarga, yaitu semua langkah dan kegiatan yang dilakukan oleh responden dalam rangka memenuhi kebutuhan pangan yang meliputi strategi produksi, akses, dan konsumsi. Hasil penelitian ini menunjukkan adanya beberapa tindakan dan strategi adaptasi yang dilakukan oleh responden di lokasi penelitian dalam rangka ketahanan pangan rumahtangga. Tindakan atau strategi adaptasi yang paling umum dan utama yang dilakukan adalah meminjam/berhutang beras atau uang. Berbeda dengan strategi adaptasi yang dilakukan petani sebagai upaya mengatasi kekurangan pangan meliputi kegiatan penyimpanan hasil panen, meminjam gabah dari keluarga atau tetangga yang kemudian akan dikembalikan pada saat musim panen yang akan datang, menjadi buruh, melakukan migrasi menjadi TKI (Nurjannah, et al., 2018). Strategi adaptasi yang dilakukan responden dapat dilihat dalam tabel berikut

Tabel 10. Sebaran Responden Menurut Strategi Adaptasi Tahun 2020

\begin{tabular}{clcc}
\hline No & \multicolumn{1}{c}{ Strategi Adaptasi } & Jumlah (Org) & Persentase (\%) \\
\hline 1 & Mengganti makanan dengan yang lebih & 1 & 2,5 \\
& murah & & 50 \\
2 & Meminjam/berhutang beras atau uang & 20 & 2,5 \\
3 & Minta pada orang tua & 1 & 45 \\
4 & Tidak melakukan & 18 & 100
\end{tabular}

Sumber: Data primer diolah

Data di atas menunjukkan bahwa 20 orang (50\%) melakukan strategi adaptasi dengan meminjam/berhutang uang atau beras ke tetangga atau di warung. Ini berarti strategi jaringan, strategi yang dilakukan dengan memanfaatkan jaringan sosial dengan cara menjalin relasi 
baik formal maupun non formal dengan lingkungan sosialnya, dan lingkungan kelembagaan, misalnya meminjam uang tetangga, mengutang di warung, memanfaatkan program kemiskinan, meminjam uang ke rentenir atau bank dan lain lain. Hal ini sejalan dengan pendapat Suharto (2009) terdapat tiga kategori Strategi bertahan hidup (coping strategis) dalam mengatasi goncangan dan tekanan ekonomi yaitu (1) Strategi aktif, yaitu strategi yang mengoptimalkan segala potensi keluarga, misalnya melakukan aktivitas sendiri, menggunakan tenaga kerja dari keluarga, memperpanjang jam kerja, memanfaatkan sumberdaya alam di lingkungan sekitar, (2) Strategi pasif, yaitu strategi bertahan hidup yang dilakukan dengan cara mengurangi pengeluaran keluarga, misalnya pengeluaraan untuk sandang, pangan, pendidikan, dan (3) Strategi jaringan, strategi yang dilakukan dengan memanfaatkan jaringan sosial dengan cara menjalin relasi baik formal maupun non formal dengan lingkungan sosialnya, dan lingkungan kelembagaan, misalnya meminjam uang tetangga, mengutang di warung, memanfaatkan program kemiskinan, meminjam uang ke rentenir atau bank. Responden melakukan strategi adaptasi dengan cara mengganti makanan dengan yang lebih murah dan minta pada orang tua masing masing 1 orang $(2,5 \%)$. Ini artinya responden melakukan strategi pasif, yaitu strategi bertahan hidup yang dilakukan dengan cara mengurangi pengeluaran keluarga, misalnya pengeluaran untuk sandang, pangan, pendidikan dan lain lain. Selebihnya 18 orang (45 \%) menyatakan tidak mengalami kekurangan, sehingga tidak ada upaya melakukan strategi adaptasi, seperti ungkapan salah seorang responden

"Untuk beras tidak kekurangan, karena dari penghasilan yang diperoleh diutamakan untuk membeli beras, dan setelah beras cukup baru kami beli kebutuhan lainnya"

Responden yang melakukan strategi adaptasi menyatakan bahwa upaya yang dilakukan tidak selalu berhasil, pernyataan ini diungkapkan oleh 15 orang $(75 \%)$ dan 5 orang menyatakan berhasil (25\%). Penyebab kekurangan pangan tidak ada pekerjaan sehingga tidak memperoleh pendapatan, hal ini diungkapkan oleh 4 orang responden (20\%), dan 16 orang $(80 \%)$ menyatakan bahwa kekurangan pangan lebih disebabkan oleh pendapatan yang tidak seimbang dengan pengeluaran, pengeluaran besar karena tuntutan kebutuhan yang meningkat. Ketika terjadi kekurangan pangan maka responden mengganti konsumsinya dengan ubi kayu, ubi jalar dan bubur, seperti ungkapan responden berikut ini

"Jika tidak ada beras maka kami makan ubi saja, karena pendapatan tidak cukup untuk beli beras, sementara untuk berhutang di warung tidak berani, khawatir tidak bisa bayar, sekarang pendapatan tidak menentu kadang ada dan kadang juga tidak ada"

\section{Perilaku Keragaman Pangan}

Perilaku responden terhadap keragaman pangan mengidentifikasi pengetahuan, sikap dan ketrampilan mereka dalam mempraktekkan keragaman pangan empat sehat lima sempurna. Untuk jelasnya dapat dilihat dalam tabel berikut.

Tabel 11. Sebaran Responden Menurut Perilaku terhadap Keberagaman PanganTahun 2020

\begin{tabular}{clcc}
\hline No & \multicolumn{1}{c}{ Perilaku Keberagaman Pangan } & Jumlah (Org) & Persentase (\%) \\
\hline 1 & Pengetahuan & 26 & 65 \\
& Faham & 14 & 35 \\
& Tidak Faham & & \\
2 & Sikap & 39 & 97,5 \\
& Positif & 1 & 2,5 \\
& Negatif & & 55 \\
3 & Keterampilan & 22 & 45 \\
& Menerapkan & 18 & 5 \\
& Tidak Menerapkan & &
\end{tabular}

Sumber: Data primer diolah

Nurjannah, S., Syarifuddin., dan Yanuartati, B.Y.E 
Data di atas menunjukkan bahwa pemahaman responden tentang keragaman pangan terdapat 26 orang (65\%) sudah memahami dan 14 orang (35\%) tidak memahami, responden tertarik dengan keberagaman pangan yang ditunjukkan oleh 39 orang $(97,5 \%)$ menunjukkan sikap positif dan 1 orang $(2,5 \%)$ menunjukkan sikap negatif. Pada komponen penerapan 22 orang $(55 \%)$ sudah melakukan keberagaman pangan dan 18 orang (45\%) tidak menerapkan.

Perilaku responden menunjukkan bahwa sebagian besar responden faham tentang keberagaman pangan, data menunjukkan bahwa dalam konsumsi sehari harinya responden sudah mengkombinasi jenis makanan seperti nasi, aneka sayur mayur, ikan, telur, tahu, tempe, buah-buahan, walaupun ada responden yang tidak selalu menerapkan kombinasi tersebut. Salah seorang responden mengungkapkan

"Sebisanya kami selalu berusaha untuk mengkonsumsi sayur, walaupun sayur yang kami beli yang murah saja sesuai dengan uang yang kami punya"

Hal ini sesuai dengan pendapat Hardinsyah, (1996) yang menyatakan bahwa pada tingkat rumahtangga, pengetahuan pangan dan gizi orang tua terutama ibu rumahtangga (isteri) diduga berpengaruh terhadap jenis pangan yang dikonsumsi sebagai refleksi dari praktek dan perilaku berkaitan dengan gizi. Sementara Adi (1997) menyatakann bahwa semakin tinggi tingkat penguasaan pengetahuan pangan dan gizi semakin besar pula proporsi rumahtangga yang tahan pangan. Diduga bahwa faktor-faktor yang berpengaruh terhadap pengetahuan pangan dan gizi adalah jenjang pendidikan formal ibu rumahtangga, penyuluhan pangan dan gizi, media informasi modern, media informasi konvensional dan latar belakang sosio budaya.

Analisis terhadap data di atas merujuk pada terdapatnya konsistensi dan inkonsisten antara sikap dan perilaku dalam menerapkan keberagaman pangan (Sarwono, S,W, 1999) . Dari 39 orang yang tertarik untuk melakukan keberagaman pangan hanya 22 orang yang menerapkan, ini menunjukkan adanya keajegan (konsistensi) dimana terdapat hubungan antara sikap dan tingkah laku. Sementara itu 18 orang tidak menerapkan keberagaman pangan, dan ini menunjukkan ketidak ajegan (inkonsistensi) dimana sikap tidak mempunyai hubungan dengan tingkah laku.

Hasil penelitian menunjukkan adanya konsistensi kontingen (keajegan yang tidak menentu) dimana hubungan antara sikap dengan tingkah laku tergantung pada faktor situasi tertentu. Dalam konteks ini dapat dijelaskan bahwa faktor pekerjaan dan pendapatan responden sebagai buruh harian yang terkadang mendapat upah, dan terkadang juga tidak ada uang sama sekali yang membatasi responden untuk selalu menerapkan keberagaman pangan.

\section{Stunting}

Stunting merupakan masalah yang berkaitan dengan berbagai faktor baik ekonomi, sosial dan budaya. Penelusuran tentang pemahaman responden tentang stunting masih terdapat responden yang tidak mengetahui tentang stunting. Hal tersebut dapat dijelaskan pada tabel berikut

Tabel 12. Sebaran Responden Menurut Informasi Awal Pemahaman tentang Stunting Tahun 2020

\begin{tabular}{clcc}
\hline No & \multicolumn{1}{c}{ Informasi Awal Stunting } & Jumlah (Org) & Persentase (\%) \\
\hline 1 & Tidak Mengetahui & 10 & 25 \\
2 & Dari Posyandu & 20 & 50 \\
3 & Penyuluhan mahasiswa KKN & 7 & 17,5 \\
4 & Mengikuti kelas ibu hamil & 2 & 5 \\
5 & Puskesmas & 1 & 2,5 \\
\hline & Jumlah & 40 & 100 \\
\hline
\end{tabular}

Sumber: Data primer diolah

Nurjannah, S., Syarifuddin., dan Yanuartati, B.Y.E 
Data pada tabel di atas menunjukkan bahwa masih terdapat 10 orang (35\%) yang tidak mengetahui tentang stunting. Selebihnya responden mengetahui stunting dari posyandu sebanyak 30 orang $(50 \%)$, dari mahasiswa KKN 7 orang $(17,5 \%)$, kegiatan posyandu dan mahasiswa KKN didampingi oleh kader di desa, terdapat sebanyak 2 orang (5\%) mendapat informasi dari kelas ibu hamil dan 1 orang $(2,5 \%)$ dari puskesmas yang menginformasikan.

Penyebab stunting adalah kurang gizi sebanyak 20 orang (50\%), artinya pola makan kurang baik karena mengkonsumsi makanan yang kurang sehat dan keragaman pangan belum maksimal misalnya tidak mengkonsumsi sayur mayur, lauk pauk sehingga asupan gizi tidak seimbang. Selanjutnya 18 orang $(45 \%)$ responden tidak mengetahui penyebab stunting, dengan kondisi seperti ini maka perlu dilakukan sosialisasi yang intensif dari pihak terkait untuk mencegah stunting. Selanjutnya sebanyak 1 orang $(2,5 \%)$ responden masing masing menyatakan bahwa penyebab stunting karena faktor lingkungan yang tidak hygenis dan adanya faktor stress pada ibu saat hamil. Hal tersebut dapat dijelaskan pada tabel berikut

Tabel 13. Sebaran Responden Menurut Penyebab Stunting Tahun 2020

\begin{tabular}{clcc}
\hline No & \multicolumn{1}{c}{ Informasi Awal Stunting } & Jumlah (Org) & Persentase (\%) \\
\hline 1 & Kurang gizi & 20 & 50 \\
2 & Tidak hygenis & 1 & 2,5 \\
3 & Stress & 1 & 2,5 \\
4 & Tidak tahu & 18 & 45 \\
\hline & Jumlah & 40 & 100 \\
\hline
\end{tabular}

Sumber: Data primer diolah

Analisis selanjutnya merujuk pada faktor penyebab stunting yang dalan konteks ini pembahasan mengacu pada faktor ekonomi, sosial, lingkungan dan budaya

a.Faktor Ekonomi

Faktor ekonomi menjelaskan tentang pendapatan, pengeluaran, jenis pekerjaan, pola dan jumlah konsusmsi. Pendapatan responden Rp. 1.657 .500 per bulan, dengan pengeluaran untuk pangan sebesar Rp. 1.215.000 per bulan, dan pengeluaran non pangan sebesar Rp. 106.975 per bulan. Pekerjaan responden adalah buruh harian dengan jumlah 28 orang $(70 \%)$ dan 12 orang $(30 \%)$ bekerja serabutan. Sementara itu istri yang ikut bekerja sebagai pedagang 6 orang $(15 \%)$ dan buruh 4 orang (10\%), selebihnya tidak bekerja sebanyak 30 orang $(75 \%)$. Kondisi ini memberikan kontribusi terhadap fenomena stunting karena ketidakmampuan responden untuk selalu stabil dalam pemenuhan pangan keluarga.

Pola dan jumlah konsumsi berkaitan dengan bagaimana cara responden memberikan makanan terhadap balita. Hasil penelitian menunjukkan bahwa $84 \%$ responden memberikan ASI pertamanya kepada bayi, namun ada responden memberikan susu formula, madu atau air gula pada bayi jika ASI tidak keluar. Hal tersebut berarti para responden tidak memberikan ASI ekslusif terhadap bayinya yang dapat menyebabkan terjadinya stunting.

Pemberian MPASI (Makanan Pendamping ASI) sebelum waktunya atau saat bayi berusia 6 bulan dapat menyebabkan terjadinya stunting. Hasil penelitian menunjukkan bahwa $60 \%$ keluarga yang memiliki balita stunting memberikan MPASI sejak usia balita kurang dari 6 bulan dengan alasan responden untuk melatih pencernaan balita untuk terbiasa menerima makanan selain ASI. Makanan pendamping yang menjadi pilihan adalah bubur tanpa dilengkapi dengan sayur mayur dan lauk pauk.

Jumlah konsumsi merujuk pada seberapa sering para responden memberikan makanan terhadap anaknya. Hasil penelitian menunjukkan bahwa responden sudah melakukan sesuai standar misalnya untuk bayi pemberian ASI dilakukan setiap dua sampai tiga jam, dan untuk balita sudah diberikan makan tiga kali sehari, walaupun ragamnya masih terbatas. 


\section{b. Faktor Sosial}

Faktor sosial merujuk pada pendidikan terakhir ibu, pengetahuan tentang stunting kesehatan ibu dan anak. Pendidikan responden sebanyak $55 \%$ tamat SD, dan ini berhubungan dengan pengetahuan responden terhadap stunting. Hasil penelitian menunjukkan bahwa responden sudah mengetahui dan memahami tentang stunting dan sudah memahaminya.

Kesehatan ibu dan anak sudah dilakukan dengan mengikuti kegiatan posyandu seperti melakukan penimbangan berat badan balita, pengukuran tinggi badan pemberian makanan sehat. Sebagian besar responden $90 \%$ sudah memiliki KMS (Kartu Menuju Sehat) sehingga orang tua dapat memantau perkembangan balita untuk mengambil tindakan secepatnya jika anak mengalami pertumbuhan lambat yang dapat menyebabkan stunting.

c. Faktor Lingkungan

Faktor lingkungan menyangkut Perilaku Hidup Bersih dan Sehat (PHBS) dan Mandi, Cuci, Kakus (MCK). Perilaku Hidup Bersih dan Sehat sudah dilakukan responden, walaupun masih ada yang tidak dilakukan secara baik misalnya pemotongan kuku saat kuku sudah panjang, dan membiarkan anak bermain di tanah tanpa menggunakan alas kaki. Hal ini mempermudah penularan penyakit penyakit seperti diare, cacingan, dan lain sebagainya karena faktor hygenitas.

Hasil penelitian untuk MCK 80 \% responden sudah memandikan balita dua kali sehari, namun ada juga yang memandikan satu kali sehari yang dilakukan pada sore atau pagi hari saja, dan ada juga yang kadang kadang mandi. Hal ini dapat dipicu karena kepemilikan kamar mandi masih terbatas. Responden melakukan MCK di tempat umum atau di sungai.

\section{e.Faktor Budaya}

Faktor budaya melihat kebiasaan masyarakat dalam memberikan makanan pada balita, dan pola asuh. Sebanyak $72,5 \%$ responden sudah menghaluskan makanannya terlebih dahulu menggunakan alat seperti tumbukan, sendok, blender, dan lain sebagainya sebelum diberikan kepada bayi. Sementara itu terdapat $22,5 \%$ responden yang pernah memberikan makanan papahan (ibu yang mengunyah makanan sebelum disuapkan kepada balita) dengan alasan bahwa sebelum anak tumbuh gigi maka makanan perlu dikunyah ibu terlebih dahulu. Budaya seperti ini tidak dibenarkan karena analisis dari sisi kesehatan tentunya tidak baik justru bisa menimbulkan penyakit karena kemungkinan ada kuman dari mulut ibu ditularkan ke anaknya.

Adanya pola asuh yang berbeda berkontribusi terhadap fenomena stunting. Sebagian responden sering menitipkan balita stunting pada orang tuanya, yang tentunya mempunyai pandangan dan cara tersendiri dalam pengasuhannya, seperti pemberian makanan yang tidak hygenis, membiarkan anak bermain di area yang kotor dan lain lain. Peralihan peran pengasuhan tersebut akan berdampak pada kesehatan anak dan dapat menyebabkan terjadinya stunting.

Analisis terhadap ketahanan pangan rumah tangga dan fenomena stunting dilakukan dengan menggunakan teori struktural fungsional dari Talcott Parsons (Muzir, I.R, 2014) . Landasan teori adalah bahwa didalam satu sistem masyarakat saling terkait satu dengan lainnnya, dimana terjadi hubungan timbal balik yang saling pengaruh mempengaruhi. Perubahan terjadi karena ada penyesuaian, diferensiasi struktural, penemuan baru, juga ada sistem sosial. Perubahan terjadi dalam sistem sosial karena adanya interaksi antara sekelompok individu dalam suasana budaya tertentu, dan unit terkecilnya adalah peranan. Terdapat empat fungsi dalam sistem sosial A G I L yaitu (1) Adaptation to the environment (A) merupakann fungsi mendasar dari peranan, (2) Goal attanment (G) merupakan peranan kolektif, (3) Integration (I) tergantung pada norma yang mengatur berbagai proses yang memberikan sumbangan terhadap implementasi nilai bersama yang telah terpola dan (4) Latency (L) merupakan fungsi nilai-nilai. 
Hasil penelitian menunjukkan bahwa terbatasnya pendapatan berpengaruh pada ketahanan pangan responden dan kondisi ini memberikan kontribusi terhadap kejadian stunting. Analisis teoritis merujuk pada hubungan timbal balik yang saling mempengaruhi dimana terganganggunya lembaga ekonomi responden berpengaruh pada Lembaga kesehatan (kejadian stunting).

Lebih jauh dapat dijelaskan bahwa responden belum melakukan fungsi adaptasi (A) dengan baik karena pendapatan menjadi faktor penghambatnya yang membatasi pada kemampuan daya beli kebutuhan pangan keluarga, sehingga pilihannya adalah membeli pangan dengan harga yang relatif murah, sehingga berpengaruh pada jenis konsumsi balita. Fungsi tujuan (G) merupakan peranan kolektif yang merujuk pada munculnya penyakit karena kondisi-kondisi sosial, dan budaya. Kejadian stunting dapat terjadi karena Perilaku Hidup Bersih dan Sehat (PHBS) yang tidak sesuai dengan anjuran kesehatan.

Fungsi Integrasi (I) mengarah pada norma yang mengatur dan terpola, misalnya seorang ibu dengan fungsi spesifik yang harus merawat dan menjaga anaknya sejak dalam kandungan, termasuk dalam mengatur gizi balita, sebab kekurangan gizi berpengaruh pada kasus stunting. Pemenuhan gizi pada kehidupan pertama balita diperlukan pendidikan dan pemahaman yang lebih luas tentang keanekaragaman pangan. Dalam konteks ini terdapat kontradiksi dimana pengetahuan ibu tentang keragaman pangan sudah baik, namun tidak diikuti dengan penerapan karena pendapatan menjadi faktor pembatas.

Fungsi Latensi (L) merupakan fungsi nilai nilai yang menyebabkan Stunting adalah perbedaan pola asuh anak antara ibu kandung dengan orang lain. Beberapa responden menitipkan balita pada orang tuanya yang condong mempunyai pemahaman yang rendah tentang penanganan balita stunting. Selain itu juga masih terdapat responden yang memberi makan pada balita dengan memapah (ibu yang mengunyah makanan untuk disuapkan kepada anaknya),budaya ini tentunya tidak mendukung dari perspektif kesehatan.

\section{Strategi dan Upaya dalam Mengatasai Masalah Stunting}

Masalah stunting di daerah penelitian sudah terjadi sejak tahun 2018, oleh karena itu diperlukan berbagai upaya dalam mengatasi masalah stunting dengan melakukan berbagai macam strategi seperti di bawah ini.

\section{a.Kegiatan Posyandu dan Pemberian Makanan Sehat}

Kegiatan posyandu yang dilakukan setiap bulan merupakan upaya yang cukup tepat dilakukan. Sebanyak $75 \%$ responden menyatakan bahwa dengan rutin mengunjungi posyandu maka perkembangan anak seperti imunisasi dasar, pertambahan berat badan, tinggi badan, kurang gizi dapat dipantau dengan baik, dengan demikian maka mempermudah penanganan terhadap kasus tersebut.

Upaya pemberian makanan sehat seperti bubur, biskuit, tetap dilakukan dengan tambahan vitamin yang ditujukan untuk membantu menjaga metabolisme tubuh balita. Program Pemberian Makanan Tambahan (PMT) Pemulihan bagi balita stunting giat dilaksanakan dalam upaya menurunkan kejadian stunting.

\section{b. Penyuluhan Tentang Stunting dan Memasyarakatkan Kelor}

Upaya penyuluhan dilakukukan untuk merubah perilaku masyarakat berkaitan dengan stunting, baik dari aspek pengetahuan, sikap dan ketrampilan. Penyuluhan yang telah dilakukan oleh pemerintah Desa terkait dengan stunting adalah: (1) sosialisasi mengenai stunting, (2) sosialisasi mengenai 1000 Hari Pertama Kehidupan, (3) sosialisasi pendewasaan usia perkawinan, dan (4) sosialisasi mengenai sanitasi lingkungan. Selain itu penyuluhan yang pernah disampaikan oleh mahasiswa KKN UNRAM 2019 tentang pemanfaatan dan pengolahan kelor menjadi beraneka macam makanan dapat dijadikan sebagai alternatif pencegahan stunting, langkah ini diharapkan agar masyarakat menanam pohon kelor di pekarangannya, sehingga tidak ada alasan untuk tidak mengkonsumsi sayur. 


\section{c. Membangun Kampung KB}

Upaya membangun kampung KB ditujukan untuk mengurangi angka stunting. Program ini dipusatkan pada dusun yang memiliki cukup banyak balita stunting. Diharapkan keberadaan kampung KB dapat mengurangi angka stunting dengan melakukan beberapa tindakan seperti (1) memberikan pelayanan kesehatan seperti posyandu, (2) memberikan konsultasi pranikah, (3) pemberdayaan ekonomi keluarga, dan (4) memberikan pemahaman tentang pengasuhan anak.

\section{KESIMPULAN DAN SARAN}

\section{Kesimpulan}

Atas dasar data hasil dan pembahasan pada penelitian ini, maka dapat ditarik kesimpulan sebagai berikut:

1. Ketahanan pangan rumah tangga masih dikategorikan agak rentan pangan karena adanya keterbatasan dalam ketercukupan ketersediaan pangan, stabilitas pangan, aksebilitas dan keterjangkauan terhadap pangan, kualitas dan keamanan pangan, sehingga melakukan beberapa strategi adaptasi untuk memenuhi pangan keluarga.

2. Perilaku terhadap keberagaman pangan menunjukkan adanya keajegan (konsistensi) antara sikap dan tingkah laku, ketidak ajegan (inkonsistensi) dimana Sikap tidak mempunyai hubungan dengan tingkah laku, dan adanya konsistensi kontingen (keajegan yang tidak menentu) dimana hubungan antara sikap dengan tingkah laku tergantug situasi tertentu

3. Faktor faktor penyebab stunting terdiri dari dari faktor ekonomi, sosial, lingkungan dan budaya. Fenomena stunting memberikan gambaran bahwa pemahaman masyarakat masih minim dalam upaya mengatasinya, sehingga pemerintah desa melakukan strategi yang terdiri dari meningkatkan kegiatan posyandu dan pemberian makanan sehat, penyuluhan tentang stunting dan memasyarakatkan tanaman kelor, membangun kampung KB. Dengan upaya ini diharapkan dapat menurunkan kejadian stunting.

\section{Saran}

Atas dasar hasil dan pembahasan pada penelitian ini, maka diajukan beberapa saran sebagai berikut:

1. Sebagai bagian dari upaya meningkatkan ketahanan pangan keluarga, pemerintah agar dapat meneruskan program yang berkaitan penanggulangan kemiskinan dengan konsep pemberdayaan masyarakat.

2. Diperlukan stategi yang lebih intensif dalam menanggulangi masalah stunting, dan ini bisa dilakukan pendekatan sosialisasi dan pembelajaran pada ibu rumah tangga tentang pentingnya pola hidup sehat. 


\section{DAFTAR PUSTAKA}

BPS Kabupaten Lombok Barat. (2020). Kecamatan Gunungsari Dalam Angka Tahun 2020. Badan Pusat Statistik Kabupaten Lombok Barat: Gerung.

Creswell. JW. (1994). Research Design Qualitative and Quantitative Approaches. SAGE Publications: London.

Dinas Kesehatan Provinsi NTB. (2017). Profil Kesehatan Provinsi NTB. Dinas Kesehatan Provinsi NTB: Mataram.

Hardinsyah, (1996). Measurement and Determinants of Food Diversity: Implication for Indonesia's Food and Nutrition Policy. [Disertasi]. Faculty of Medicine University of Quensland.

Hardjana, (1993). Orientasi Perilaku Konsumen Tentang Masalah Pangan dan Gizi dari Sumber Hayati kelautan. Risalah Widya Karya Nasional Pangan dan Gizi. LIPI: Jakarta.

Miles, MB. \& Huberman AM. (1992). Analisis Data Kualitatif, Buku Sumber Tentang Metode-Metode Baru. Terjemahan dari Analyzing Qualitative Data : A Source Book for New Methods. UI Press. Jakarta.

Muzir, I. R. (2014). Teori Sosiologi Dari Teori Sosiologi Klasik Sampai Perkembangan Mutakhir Teori Sosial Postmodern. Edisi Bahasa Indonesia. Kreasi Wacana: Bantul.

Neuman, WL. (1994). Social Research Method : Qualitative and Quantitative Approach (2 nd Edition). Allyn and Bacon: Sydney.

Nisbet. J. \& J. Watt. (1994). Studi Kasus Sebuah Panduan Praktis. PT. Gramedia Widiasarana Indonesia: Jakarta.

Nurjannah, S, Sauqi, A., \& Syarifuddin. (2018). Respon Rumahtangga Petani dan Strategi Adaptasi Petani Terhadap Ketahan Pangan : Kasus pada Dua Desa Di Kecamatan Preaya Barat Daya Kabupaten Lombok Tengah.Penelitina Dana PNBP Universitas Mataram.

Sauqi, A., Nurjannah,S., \& Syarifuddin. (2019) . Kajian Ketahanan Pangan Rumahtangga Petani Pasca Gempa Bumi di Kecamatan Kayangan Kabupaten Lombok Utara. Penelitina Dana PNBP Universitas Mataram.

Sarwono, S.W. (1999). Psikologi Sosial (Individu dan Teori-Teori Psikologi Sosial). Balai Pustaka: Jakarta.

Suhardjo. (1996). Pengertian dan Kerangka Pikir Ketahanan Pangan Rumahtangga. Dalam Laporan Lokakarya Ketahanan Pangan Rumahtangga. Departemen Pertanian UNICEF.

Suharto. (2009). Kemiskinan dan Perlindungan Sosial di Indonesia. Alfabeta: Bandung.

Tim Nasional Percepatan Penangulangan Kemiskinan. (2017). 100 Kabupaten/Kota Prioritas untuk Intervensi Anak Kerdil (Stunting). Sekretariat Wakil Presiden Republik Indonesia: Jakarta Pusat.

Zid, M \& Alkhudri, AT,. (2016). Sosiologi Pedesaan. PT. Raja Grafindo Persada: Jakarta. 